\title{
Changes in Protein Expression Associated with Chilling Injury in Tomato Fruit
}

\author{
Misael O. Vega-García, Greici López-Espinoza, Jeanett Chávez Ontiveros, \\ José J. Caro-Corrales, Francisco Delgado Vargas, and José A. López-Valenzuela ${ }^{\mathbf{1}}$ \\ Facultad de Ciencias Químico-Biológicas, Universidad Autónoma de Sinaloa, Cd. Universitaria, \\ Av de las Américas y Josefa Ortíz S/N, Culiacán, Sin., México 80010
}

\begin{abstract}
AdDitional INDEX wORDS. Solanum lycopersicum, postharvest, oxidative stress, cold response, proteomics
Abstract. Tomato (Solanum lycopersicum) fruit is susceptible to chilling injury (CI), a physiological disorder caused by low, non-freezing temperatures that affects fruit postharvest quality. Little is known about the biochemical basis of CI, and the aim of this study was to identify proteins related to this disorder in 'Imperial' tomato fruit. CI and protein expression changes were analyzed during fruit ripening $\left(0,4,8\right.$, and 12 days at $\left.21^{\circ} \mathrm{C}\right)$ after storage under chilling $\left(5^{\circ} \mathrm{C}\right)$ and non-chilling conditions $\left(21^{\circ} \mathrm{C}\right)$ for 5,15 , and 25 days. The main $\mathrm{CI}$ symptoms observed were uneven fruit ripening and color development, pitting, and decay. Protein analysis of two-dimensional gels showed that $6 \%$ of the detected spots $(\approx 300)$ changed their expression in response to cold. The identified proteins are involved in carbon metabolism, oxidative stress, photosynthesis, and protein processing and degradation; two were related to cold stress, showing higher accumulation in non-damaged tissue of chilled fruit: thioredoxin peroxidase (TPxI) and glycine-rich RNA-binding protein (GR-RBP). This is the first report suggesting an important role for TPXI and GR-RBP in cold response during tomato fruit ripening, and they may be acting through redox sensing and regulation of gene expression at low temperature. These enzymes and the other chilling-related proteins might be working together to maintain the cellular homeostasis under cold stress conditions.
\end{abstract}

Tomato is one of the most popular and economically important vegetables in the world (Madhavi and Salunkhe, 1998). However, it is susceptible to chilling injury (CI), a physiological disorder that affects mainly tropical and subtropical products when they are exposed to low non-freezing temperatures (Saltveit and Morris, 1990). The minimum safe temperature for tomato fruit storage is about $12{ }^{\circ} \mathrm{C}$, and the main visible $\mathrm{CI}$ symptoms are uneven ripening and color development, dark sunken lesions on the peel surface (pitting), and decay (Cheng and Shewfelt, 1988). These visible symptoms generally appear when tomatoes are transferred to nonchilling conditions after being stored at low temperature for longer than 1 week (Lurie and Sabehat, 1997), although cell structure alterations have been observed without a ripening period after prolonged chilling (Gomez et al., 2009).

The mechanisms involved in the CI of plant tissues are poorly understood; the phase transition of the cell membrane lipids during chilling has been considered the detonating event of the CI symptoms (Lyons, 1973), and more recent reports have shown ultrastructural changes of membranes and organelles induced by chilling (Marangoni et al., 1989; Yang et al., 2009). An oxidative stress response has been related to the appearance of the CI symptoms, suggesting that the antioxidant system, including superoxide dismutases (SOD), peroxidases, catalases (CAT), and glutathione reductase (GR), confers protection to the tissue against cold (Hodges et al., 2004; Malacrida et al., 2006). Oxidative damage occurs when this system fails to limit the accumulation of reactive oxygen species such as superoxide and hydrogen peroxide (Kerdnaimongkol and

Received for publication 20 Nov. 2009. Accepted for publication 14 Jan. 2010. This work was supported by grants from Consejo Estatal de Ciencia y Tecnología-Sinaloa and Programa de Fomento y Apoyo a Proyectos de Investigación-Universidad Autónoma de Sinaloa. G.L.-E. was the recipient of a scholarship from CONACYT-Mexico.

${ }^{1}$ Corresponding author. E-mail: jalopez@uas.uasnet.mx.
Woodson, 1999), leading to inactivation of enzymes, lipid peroxidation, protein degradation, and DNA damage (Foyer and Noctor, 2005). Ascorbate peroxidase (APX) is one of the main enzymes involved in detoxification of $\mathrm{H}_{2} \mathrm{O}_{2}$, and its overexpression in tomato confers tolerance to chilling and salt stress (Wang et al., 2005), although it has been shown that the capacity of the ascorbate-mediated antioxidant system is not enough to protect the cell from photoinhibition under oxidative stress (Shikanai et al., 1998). Malacrida et al. (2006) reported that the antioxidant response of chilled 'MicroTom' tomato fruit was mediated by CAT and GR but not by SOD or APX, although Gomez et al. (2009) suggested that activation of SOD and APX is an immediate response to chilling stress in this cultivar. The $\mathrm{H}_{2} \mathrm{O}_{2}$ that is not detoxified by enzymes such as APX and CAT could also be decomposed by peroxiredoxins (Prx), thiol-dependent peroxidases that can reduce a wide range of active oxygen species (Tripathi et al., 2009).

Chilling-induced changes in the redox state of the cell can trigger a signal transduction pathway that regulates gene expression; the abundance and activities of functional proteins change and might work cooperatively to establish a new redox homeostasis under the stress condition (Foyer and Noctor, 2005). Proteomic studies have identified several proteins associated with plant tissue responses at low temperature; they are involved in several processes, including signal transduction, RNA processing, translation, protein processing, redox homeostasis, photosynthesis, and metabolisms of carbon, nitrogen, sulfur, and energy (Yan et al., 2006). Some of the proteins identified more frequently in these studies include peroxidases, heat shock and RNA-binding proteins, rubisco, and energy metabolism enzymes (Renaut et al., 2006). A recent transcriptomic analysis of chilled 'Micro-Tom' tomato fruit identified several housekeeping genes upregulated by cold and a dehydrin homolog, which was proposed as a transcriptional 
marker of cold stress (Weiss and Egea-Cortines, 2009). Nevertheless, the biochemical bases of CI are still poorly understood and there is little information about cold-responsive proteins in tomato fruit.

To identify proteins related to CI, we compared the protein expression patterns during ripening $\left(21^{\circ} \mathrm{C}\right)$ of 'Imperial' tomato fruit previously stored under non-chilling $\left(12^{\circ} \mathrm{C}\right)$ and chilling $\left(5^{\circ} \mathrm{C}\right)$ conditions. This study allowed the identification of some chilling-related proteins and their potential roles in chilling response mechanisms are discussed. To our knowledge, this is the first report about tomato fruit proteome changes under chilling stress conditions.

\section{Materials and Methods}

Materials AND StORAGE CONDitions. Mature-green 'Imperial' tomato fruit were obtained from a local producer and were selected based on size uniformity, color, and absence of defects. They were washed (150 mg. $\left.\mathrm{L}^{-1} \mathrm{NaClO}, \mathrm{pH} 6.8\right)$ and divided in two groups: one group was stored at $5{ }^{\circ} \mathrm{C}$ [CI treatment (CIT)] and the other at $12{ }^{\circ} \mathrm{C}$ [commercial refrigeration treatment (CRT)], both during 5, 15, and $25 \mathrm{~d}$ at $85 \%$ to $90 \%$ relative humidity $(\mathrm{RH})$. After this storage, fruit were kept in a ripening room $\left(21^{\circ} \mathrm{C}, 85 \% \mathrm{RH}\right)$ for $0,4,8,12$, and $16 \mathrm{~d}$. Protein analyses were performed by triplicate at harvest and after $0,4,8$, and $12 \mathrm{~d}$ of ripening in fruit previously stored for 5, 15, and $25 \mathrm{~d}$ at CIT and CRT. For this protein comparative analysis, the whole pericarp tissue of ripening tomato fruit was used. On the other hand, damaged and non-damaged tissues of the same fruit exposed $25 \mathrm{~d}$ at $5{ }^{\circ} \mathrm{C}$ and ripened $8 \mathrm{~d}$ at $21{ }^{\circ} \mathrm{C}$ were used to identify protein changes associated to CI symptoms. Pericarp tissues were frozen with liquid nitrogen and stored at $-70{ }^{\circ} \mathrm{C}$ until use.

CI INDEX (CII). This index was determined in 35 fruit per each of the three levels of storage at $5{ }^{\circ} \mathrm{C}(5,15$, and $25 \mathrm{~d})$, during the ripening period according to Ding et al. (2002) with some modifications. The criteria to evaluate the symptoms were: $\mathrm{U}=$ uneven ripening and color development, $\mathrm{P}=$ pitting, and $\mathrm{D}=$ decay. The severity of the symptoms was assessed visually as injury level (IL) using a five-point scale based on the percentage of tissue affected for each criterion $(0=$ no injury, $1=<10 \%, 2=11 \%$ to $25 \%, 3=26 \%$ to $40 \%, 4=>40 \%$ ). CII was used to measure the CI damage for each fruit and it was calculated by the following expression: CII $=($ ILU + ILP + ILD) $/ 3$. The CII reported corresponds to the average of 35 fruit per level of storage at $5^{\circ} \mathrm{C}$.

Protein extraction. Protein was extracted as described by Wang et al. (2006) with some modifications. Frozen tomato pericarp tissue was ground in liquid nitrogen with a mortar and pestle to obtain a fine powder. About $8 \mathrm{~g}$ of powdered tissue was homogenized with $10 \mathrm{~mL}$ of $10 \%(\mathrm{w} / \mathrm{v})$ trichloroacetic acid in acetone for $5 \mathrm{~min}$, followed by centrifugation $\left(11,000 g_{\mathrm{n}}, 15\right.$ $\min , 4^{\circ} \mathrm{C}$ ), and the supernatant was discarded; the pellet was washed two more times, first with $80 \%(\mathrm{v} / \mathrm{v})$ methanol plus 0.1 $\mathrm{mol} \cdot \mathrm{L}^{-1}$ ammonium acetate and then with $80 \%(\mathrm{v} / \mathrm{v})$ acetone using the same conditions. Washed tissue was transferred to 1.5-mL tubes and dried to remove residual solvents. About $0.2 \mathrm{~g}$ of dry powder was resuspended in $0.6 \mathrm{~mL}$ of phenol $(\mathrm{pH} \mathrm{8.0;}$ Sigma, St. Louis) and $0.6 \mathrm{~mL}$ of SDS buffer $\left[0.1 \mathrm{~mol} \cdot \mathrm{L}^{-1}\right.$ Tris$\mathrm{HCl}, \mathrm{pH} 8.0,2 \%(\mathrm{w} / \mathrm{v}) \mathrm{SDS}, 30 \%(\mathrm{w} / \mathrm{v})$ sucrose, and 5\% (v/v) 2-mercaptoethanol]. The mixture was vortexed thoroughly, incubated for $5 \mathrm{~min}$, and centrifuged $\left(16000 \mathrm{~g}_{\mathrm{n}}, 5 \mathrm{~min}\right)$ to sep- arate the phenol phase, from which the proteins were precipitated with five volumes of $0.1 \mathrm{~mol} \cdot \mathrm{L}^{-1}$ ammonium acetate in methanol $\left(-20{ }^{\circ} \mathrm{C}, 30 \mathrm{~min}\right)$. Proteins were recovered by centrifugation $\left(16000 g_{\mathrm{n}}, 5 \mathrm{~min}\right)$; the pellet was washed with $100 \%$ methanol followed by $80 \%(\mathrm{v} / \mathrm{v})$ acetone and was then dried to remove residual solvents. The protein pellet was resuspended in $0.2 \mathrm{~mL}$ of rehydration buffer $\left[8 \mathrm{~mol} \cdot \mathrm{L}^{-1}\right.$ urea, 2\% (w/v) CHAPS, $10 \mathrm{~mm}$ DTT, and $0.2 \%$ (v/v) ampholytes, $\mathrm{pH}$ 3-10], and the concentration was determined according to Bradford (1976) using bovine serum albumin as standard.

Protein Separation and image analysis. Proteins were separated by two-dimensional polyacrylamide gel electrophoresis (2D-PAGE). For the first dimension, resuspended proteins were supplemented with $0.001 \%$ (w/v) bromophenol blue, and $500 \mu \mathrm{g}$ was loaded by rehydration into $17-\mathrm{cm}$ immobilized $\mathrm{pH}$ (5-8) gradient strips (Bio-Rad, Hercules, CA). Isoelectrofocusing (IEF) was conducted with a Protean IEF system (Bio-Rad) using the voltage and time recommended by the manufacturer $(250 \mathrm{~V}, 20 \mathrm{~min} ; 10000 \mathrm{~V}, 2.5 \mathrm{~h}$; and $10000 \mathrm{~V}, 40000 \mathrm{Vh})$. After IEF, proteins were reduced with dithiothreitol [0.375 $\mathrm{mol} \cdot \mathrm{L}^{-1}$ Tris- $\mathrm{HCl}$, pH $8.8,0.13 \mathrm{~mol} \cdot \mathrm{L}^{-1} \mathrm{DTT}, 6 \mathrm{~mol} \cdot \mathrm{L}^{-1}$ urea, $20 \%(\mathrm{v} / \mathrm{v})$ glycerol, and 2\% (w/v) SDS] and then alkylated with iodoacetamide $\left[0.375 \mathrm{~mol} \cdot \mathrm{L}^{-1}\right.$ Tris- $\mathrm{HCl}, \mathrm{pH} 8.8,0.135 \mathrm{~mol} \cdot \mathrm{L}^{-1}$ iodoacetamide, $6 \mathrm{~mol} \cdot \mathrm{L}^{-1}$ urea, $20 \%(\mathrm{v} / \mathrm{v})$ glycerol, and $2 \%(\mathrm{w} /$ v) SDS]. The IEF strip was placed on the top of a $12.5 \%(\mathrm{w} / \mathrm{v})$ polyacrylamide gel (SDS-PAGE) and the proteins were separated by size at constant current $(40 \mathrm{~mA})$ with a Protean II XL system (Bio-Rad). The gels were stained with Coomassie blue R-250 and the images were acquired with a Chemidoc XRS documentation system (Bio-Rad). Image analysis was conducted using the PDQuest software (Bio-Rad). Spot detection and matching between gels were performed automatically, followed by manual verification. Spot densities were normalized against total density in-gel image to compensate for experimental variations in size and intensity. Normalized spot densities were averaged for three different gels (three replicates).

Protein identification. Differentially expressed proteins were identified by tandem mass spectrometry (MS/MS). Protein spots were excised from the gels and washed with distilled water, followed by $50 \%(\mathrm{v} / \mathrm{v})$ acetonitrile, acetonitrile $/ 0.1$ $\mathrm{mol} \cdot \mathrm{L}^{-1}$ ammonium bicarbonate (1:1), and $100 \%$ acetonitrile. Proteins were then reduced, carbamidomethylated, digested with trypsin, and the resulting peptides were extracted from the gel as described by Shevchenko et al. (1996). The peptide mixture was analyzed using a micro-mass spectrometer (Micromass Q-ToF; Waters, Beverley, MA), where some of the peptides were sequenced from their collision-induced dissociation (CID) spectra using the MassLynx software (Waters) provided with the equipment. The sequences obtained were compared with those in databases using the MS Blast search tool described by Shevchenko et al. (2001) and the MS/MS search tool provided by the Mascot program (Perkins et al., 1999).

Statistical ANAlysis. Data were analyzed by analysis of variance (ANOVA) using STATGRAPHICS PLUS (version 5.1; Statistical Graphics, Warrenton, VA). For CII, factors were time of storage at $5{ }^{\circ} \mathrm{C}(5,15$, and $25 \mathrm{~d})$ and time of ripening at $21{ }^{\circ} \mathrm{C}(0,4,8,12$, and $16 \mathrm{~d})$; values are the mean of 35 fruit. For protein expression changes between chilling and non-chilling conditions (spots 1 and 2), factors were storage at low temperature (CRT and CIT), time of storage at low temperature $(5,15$, and $25 \mathrm{~d})$, and time of ripening at $21^{\circ} \mathrm{C}(0,4,8$, and $12 \mathrm{~d})$; 
for differentially expressed proteins in chilled fruit (spots 3-9), the factor was CI damage (damaged and non-damaged tissue). Optical density (OD) was measured by triplicate. Means were compared by the least significant difference (LSD, $\alpha=0.05$ ) multiple range test.

\section{Results and Discussion}

CI. Figure $1 \mathrm{~A}$ shows the $\mathrm{CII}$ during the ripening $\left(21^{\circ} \mathrm{C}\right)$ of tomato fruit previously stored at low temperature $\left(5^{\circ} \mathrm{C}\right)$. CI symptoms were not observed immediately after the lowtemperature storage $\left(0 \mathrm{~d}\right.$ at $\left.21{ }^{\circ} \mathrm{C}\right)$. There were no significant differences in CII during the ripening of fruit stored for $5 \mathrm{~d}$ at $5{ }^{\circ} \mathrm{C}$ reaching a value of about 0.25 . Some of these fruit showed uneven color development during the first days of storage at $21^{\circ} \mathrm{C}$, but they developed a normal red color by the end of the ripening period and were still marketable. After $15 \mathrm{~d}$ of storage at $5{ }^{\circ} \mathrm{C}$, CII increased more than 2 -fold from day 4 to 8 of ripening; this value $(\approx 0.9)$ was not different among treatments during the last $8 \mathrm{~d}$ of ripening. The symptoms observed in these fruit were mainly uneven ripening and color development,

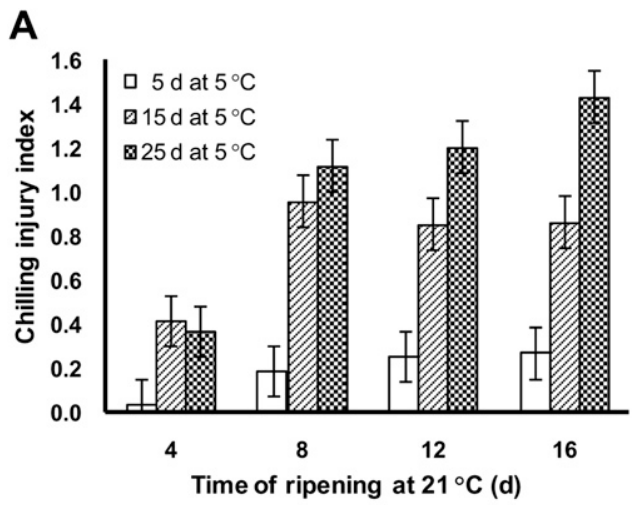

B

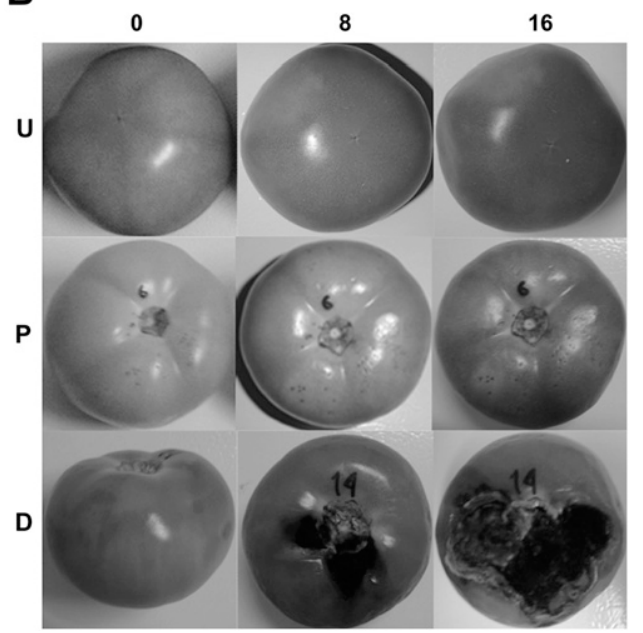

Fig. 1. CI during ripening $\left(21^{\circ} \mathrm{C}\right)$ of 'Imperial' tomato fruit previously stored at low temperature. (A) CI index (CII) of fruit stored for 5,15 , and $25 \mathrm{~d}$ at $5{ }^{\circ} \mathrm{C}$. CII was on a scale of 0 to $4(0=$ no injury; $1=<10 \% ; 2=11 \%$ to $25 \% ; 3=26 \%$ to $40 \% ; 4=>40 \%$ of the surface area). CII was zero immediately after the low temperature storage $\left(0 \mathrm{~d}\right.$ at $\left.21^{\circ} \mathrm{C}\right)$. Vertical bars indicate $\mathrm{LSD}=0.23(\alpha=0.05)$; means are significantly different when bars do not horizontally overlap. (B) CI symptoms observed in fruit stored for $25 \mathrm{~d}$ at $5{ }^{\circ} \mathrm{C} ; \mathrm{U}=$ uneven ripening and color development, $\mathrm{P}=$ pitting, $\mathrm{D}=$ decay.

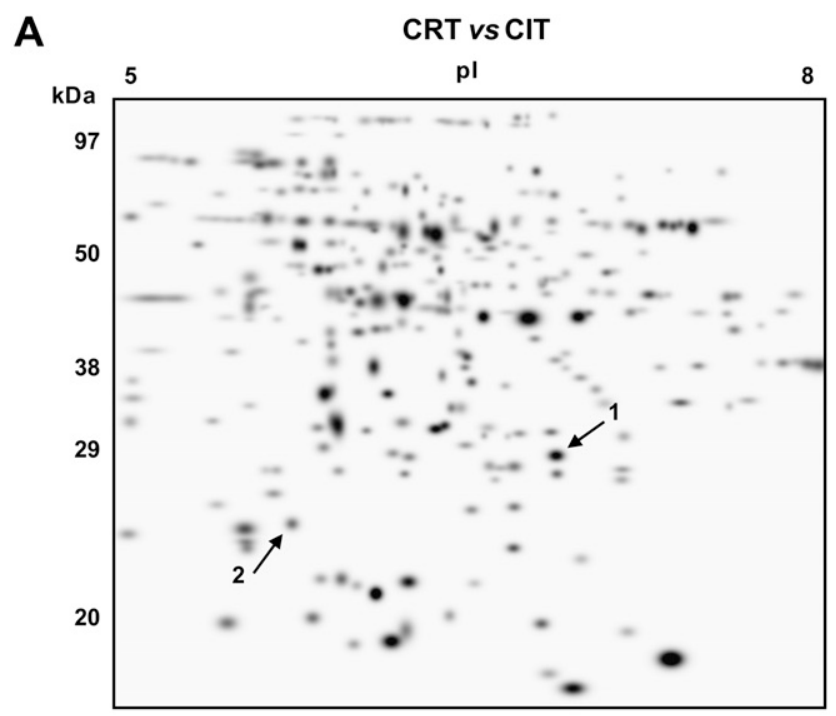

B

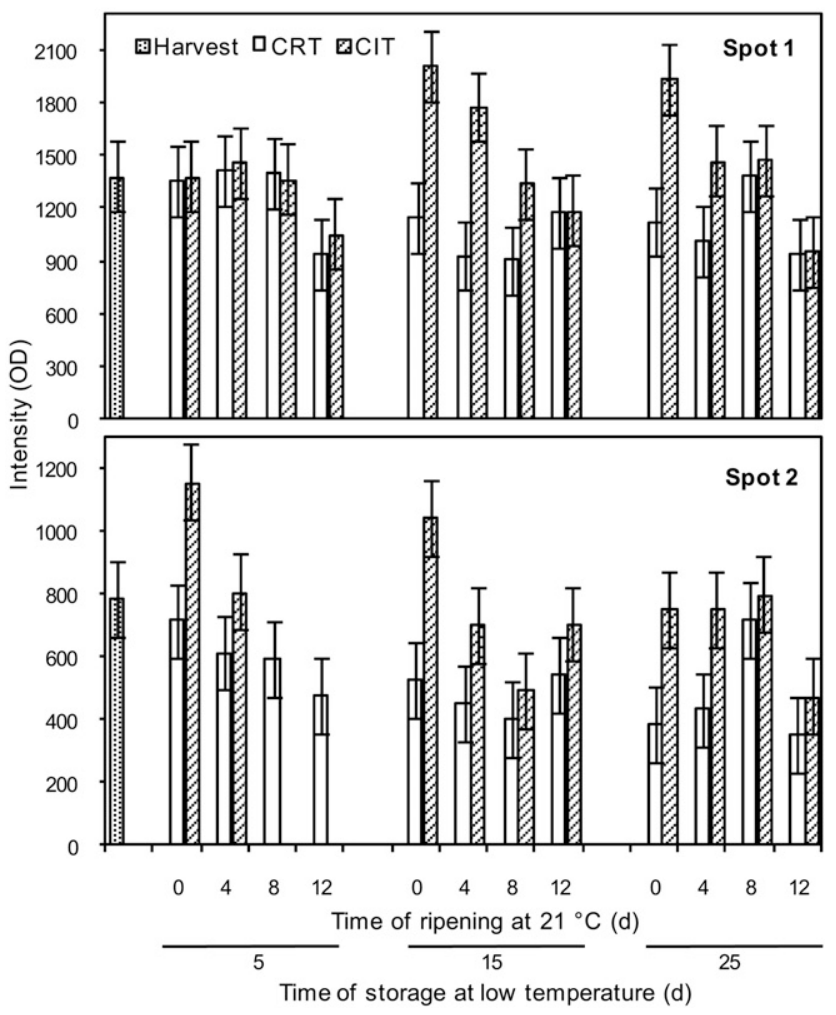

Fig. 2. Protein expression changes during ripening of 'Imperial' tomato fruit previously stored at low temperature. (A) Representative two-dimensional gel showing the proteins (arrows) differentially expressed between ripening fruit $\left(4 \mathrm{~d}\right.$ at $\left.21{ }^{\circ} \mathrm{C}\right)$ prestored under commercial refrigeration treatment [CRT $\left(12{ }^{\circ} \mathrm{C}\right)$ ] and CI treatment [CIT $\left.\left(5^{\circ} \mathrm{C}\right)\right]$ for $25 \mathrm{~d}$. The molecular masses in kilodaltons $(\mathrm{kDa})$ of prestained protein markers are shown on the left and the linear range of isoelectric points (pI) are above. Protein spots were identified by tandem mass spectrometry and are listed in Table 1. (B) Quantification of differentially expressed proteins during ripening $\left(0,4,8\right.$, and $12 \mathrm{~d}$ at $\left.21^{\circ} \mathrm{C}\right)$ of tomato fruit prestored at CRT or CIT for 5, 15, and $25 \mathrm{~d}$. Optical density (OD) values are the mean of three replicates. Bars indicate the LSD $(\alpha=0.05)$; means are significantly different when bars do not horizontally overlap. For spots 1 and $2, \mathrm{LSD}=396$ and 238, respectively. 
followed by pitting, and to a lesser extent, the presence of decay by the end of the ripening period. About $80 \%$ of these fruit were still adequate for marketing after $12 \mathrm{~d}$ of ripening, but after $16 \mathrm{~d}$, they were over-ripened and very soft. On the other hand, the CI damage of fruit exposed for $25 \mathrm{~d}$ at $5{ }^{\circ} \mathrm{C}$ was significantly higher after $8 \mathrm{~d}$ at $21^{\circ} \mathrm{C}$, with $\mathrm{CII}$ values reaching 1.4 after $16 \mathrm{~d}$ of ripening (Fig. 1A). Figure 1B shows the CI symptoms developed by these fruit: uneven ripening and color development $(\mathrm{U})$, pitting $(\mathrm{P})$, and decay (D); these symptoms are similar to those previously observed by Ding et al. (2002) and their severity increased with the advance of ripening, reaching irreversible damage. Fruit skin never developed a uniform red color and had yellow-green areas at the end of the ripening period (Fig. 1B, row $\mathrm{U}$ ). This was also observed in fruit that developed pitting (Fig. 1B, row P). Fruit showed decay after $4 \mathrm{~d}$ at $21^{\circ} \mathrm{C}$ and they were considered not adequate for marketing after $8 \mathrm{~d}$ of ripening (Fig. 1B, row D). Lurie and Sabehat (1997) reported similar results for 'Daniella' tomato fruit stored during 3 weeks at $2{ }^{\circ} \mathrm{C}$, where a non-uniform color was observed in the skin during ripening and the presence of decay was severe.

Storage at chilling temperature affected fruit external color development independently of the time of exposure, while pitting and decay were important symptoms during ripening of fruit previously stored for 15 and $25 \mathrm{~d}$ under chilling conditions. Uneven ripening and color development as the main chilling stress symptoms can be attributed to the fact that chloroplasts are the first organelles that undergo structural changes under low temperature conditions (Marangoni et al., 1989; Yang et al., 2009). Because these and other chilling-induced metabolic alterations could be related to changes in protein abundance, we decided to analyze the protein expression patterns of tomato fruit stored under chilling and non-chilling conditions.

Protein expression Changes. The effect of low temperature storage $\left(12{ }^{\circ} \mathrm{C}\right.$, CRT; $5{ }^{\circ} \mathrm{C}$, CIT) on tomato pericarp protein expression was studied during ripening at $21{ }^{\circ} \mathrm{C}$ (Fig. 2). The analysis of Coomassie-stained two-dimensional gels with PDQUEST detected about 300 protein spots highly reproducible in the three replicates (Fig. 2A). Three of these proteins were differentially expressed between tomato fruit previously stored for 5 or $15 \mathrm{~d}$ under CIT and CRT; two of these proteins
(Fig. 2A) were identified by MS/MS as triose phosphate isomerase (TPI; spot 1) and TPxI (spot 2) (Table 1). In general, fruit stored at CIT showed higher expression of these two proteins compared with those stored at CRT (Fig. 2B). After $5 \mathrm{~d}$ at CRT, the expression pattern of TPI and TPxI during fruit ripening $\left(21^{\circ} \mathrm{C}\right)$ was similar to that reported by Rocco et al. (2006). Remarkably, TPxI expression in fruit with $5 \mathrm{~d}$ at CIT was significantly higher up to $4 \mathrm{~d}$ of ripening while TPI accumulation did not change (Fig. 2B). As it was discussed above, tomato fruit with $5 \mathrm{~d}$ at CIT showed almost normal ripening and all of them were marketable. The greatest difference in TPI expression between CRT and CIT was observed in fruit with an altered ripening as indicated by high CII values (Figs. 1A and 2B). Consequently, TPxI could be more important in the maintenance of fruit integrity during the initial stages of storage at $5{ }^{\circ} \mathrm{C}$ (Figs. $1 \mathrm{~A}$ and 2B). The differential expression of both enzymes was more significant during the first days of ripening, before the CI symptoms appeared, suggesting that the increased accumulation of these enzymes may be a cellular response aiming to protect the tissues against the chilling stress.

TPxI is a member of the peroxiredoxin family that catalyzes the reduction of a broad range of different peroxides, including $\mathrm{H}_{2} \mathrm{O}_{2}$, alkyl hydroperoxides, and peroxinitrite (Tripathi et al., 2009). These proteins are believed to play important roles in plants under various abiotic stress conditions, including chilling (Yan et al., 2006). Redox homeostasis has been suggested as a metabolic interface between stress perception and physiological responses (Foyer and Noctor, 2005). Reactive oxygen species (ROS) produced under stress can signal some compensatory responses, but they can also damage cellular components. Plants can regulate redox homeostasis scavenging ROS by peroxidases such as TPxI because it has been suggested that these peroxiredoxin isoforms (Type II) decompose the $\mathrm{H}_{2} \mathrm{O}_{2}$ that escapes from the detoxification by other enzymes such as catalases or ascorbate peroxidases (Tripathi et al., 2009). The reactions catalyzed by these enzymes require reduced glutathione as substrate, providing a possible link between the higher TPxI expression observed in CIT tomato fruit (spot 2, Fig. 2) and the increased GR activity and glutathione levels reported in

Table 1. Identification by tandem mass spectrometry of chilling-related proteins in 'Imperial' tomato fruit.

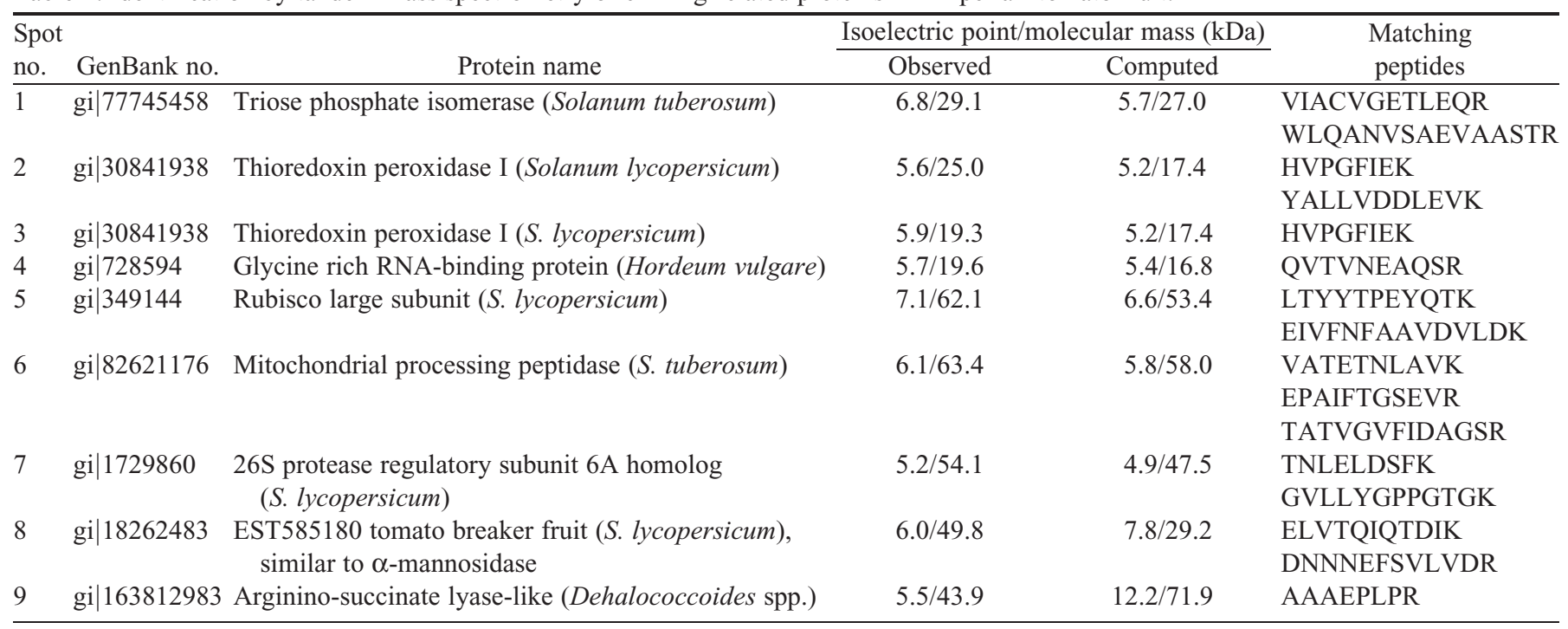


prechilled 'Micro-Tom' tomato fruit (Gomez et al., 2009; Malacrida et al., 2006). The expression of TPxI was higher in CIT fruit after only $5 \mathrm{~d}$ of chilling (Fig. 2B), suggesting an important role for this enzyme in the cellular redox sensing and homeostasis to protect the tissue against cold-induced oxidative stress.

TPI is a glycolytic enzyme that catalyzes the isomerization of dihydroxyacetone phosphate to glyceraldehyde 3-phosphate. An increase in the accumulation of this enzyme under cold stress conditions has also been reported in other species and could be part of a metabolic adjustment to establish a new cellular homeostasis (Cho et al., 2007; Rodriguez-Vargas et al., 2002). The increase in the expression of this protein in CIT fruit occurred after 15 and $25 \mathrm{~d}$ of chilling (Fig. 2B), which is consistent with a previous study reporting that the respiration rate of green tomato fruit prechilled for $28 \mathrm{~d}$ at $4{ }^{\circ} \mathrm{C}$ was significantly higher than that of non-chilled fruit (Malacrida et al., 2006). TPI upregulation might be the result of a low cellular efficiency in the energy production induced by severe structural damage. A similar increase in TPxI expression was observed that could be responsible for removal of the excess $\mathrm{H}_{2} \mathrm{O}_{2}$ generated by these energy-producing processes. The upregulation of TPI has been also observed by transcriptomic analysis of cold-stressed $\left(6^{\circ} \mathrm{C}\right)$ 'Micro-Tom' tomato fruit (Weiss and Egea-Cortines, 2009).

Fruit pericarp tissue, including areas with and without CI symptoms, was mixed for the CRT versus CIT comparative analysis, which probably masked some differentially expressed proteins among the treatments. To identify proteins that may be directly related to the CI symptoms, we analyzed damaged and non-damaged pericarp tissues of the same fruit exposed $25 \mathrm{~d}$ at $5{ }^{\circ} \mathrm{C}$ and ripened $8 \mathrm{~d}$ at $21^{\circ} \mathrm{C}$ (Fig. 3A). This analysis detected nine differentially expressed polypeptides and seven were successfully identified by MS/MS: TPxI (spot 3), GR-RBP (spot 4), rubisco large subunit (spot 5), mitochondrial processing peptidase (MPP, spot 6), 26S proteasome (26SP) ATPase subunit (spot 7), putative $\alpha$-mannosidase (spot 8), and argininosuccinate lyase-like (spot 9) (Table 1).

TPxI (spot 3) and GR-RBP (spot 4) were more abundant in chilled pericarp tissues without symptoms than those damaged (Fig. 3). As indicated above, TPxI appears to play an important role in maintaining cellular redox homeostasis, and the increased accumulation of this enzyme in healthy tissue may reflect a more effective decomposition of ROS that escape from the detoxification by other antioxidant systems. GR-RBPs contain a N-terminal RNA recognition motif and a C-terminal glycine-rich region, playing an important role in plant responses to environmental stresses such as tissue acclimatization at low temperature, a function that has been demonstrated for this type of proteins in Arabidopsis thaliana (Kim et al., 2005, 2007a). GR-RBPs appear to exert cold tolerance, modulating the expression of several genes through their chaperone activity, unfolding the RNA secondary structure to facilitate efficient translation at low temperature (Kim et al., 2007b). Thus, the higher expression of GR-RBP in healthy tissue could be favoring changes in the abundance and activities of target proteins that might work cooperatively to establish a new cellular homeostasis under chilling stress.

The MPP (spot 6) and 26SP ATPase subunit (spot 7) were more abundant in damaged pericarp tissues (Fig. 3). MPP removes the N-terminal targeting signals from proteins imported into mitochondria (Emmermann et al., 1993) and because oxidative stress is associated with significant decreases
A Non-damaged vs damaged tissue

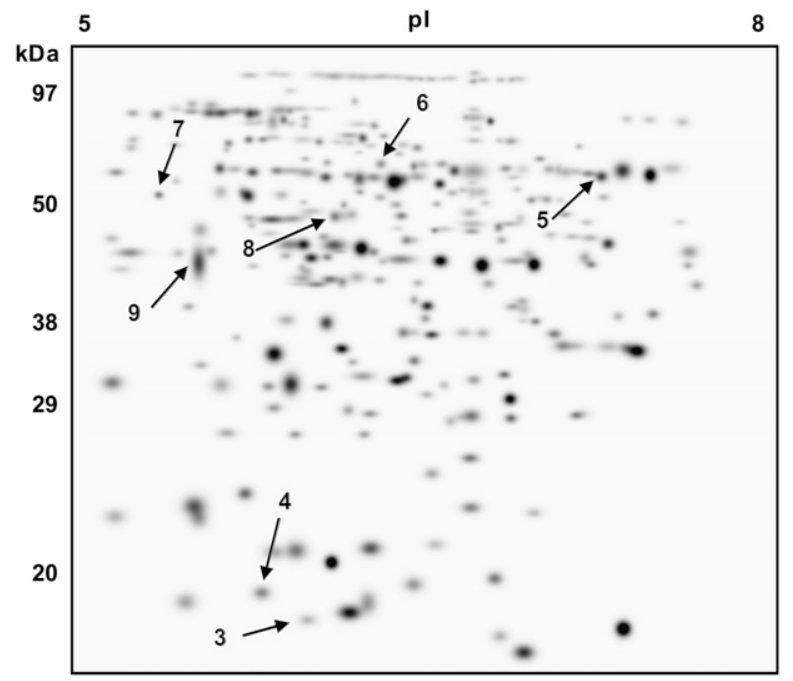

B

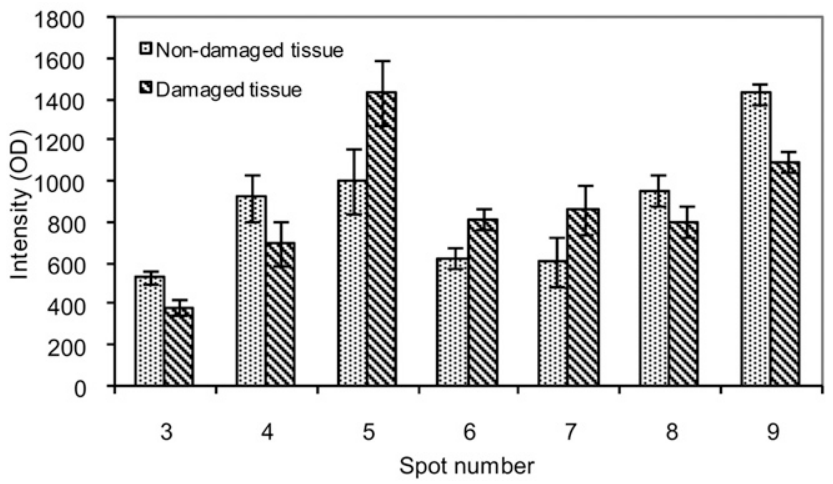

Fig. 3. Protein expression changes between non-damaged and damaged pericarp tissue of chilled 'Imperial' tomato fruit. (A) Two-dimensional gel showing the proteins (arrows) differentially expressed between non-damaged and damaged pericarp tissues of tomato fruit stored at $5^{\circ} \mathrm{C}$ for $25 \mathrm{~d}$ plus $8 \mathrm{~d}$ at $21^{\circ} \mathrm{C}$. The molecular masses in kilodaltons of prestained protein markers are shown on the left and the linear range of isoelectric points (pI) are above. Protein spots were identified by tandem mass spectrometry and are listed in Table 1. (B) Quantification of spot proteins differentially expressed between nondamaged and damaged pericarp tissue of the same chilled tomato fruit. Optical density (OD) values are the mean of three replicates. Bars indicate the LSD $(\alpha=0.05)$; means are significantly different when bars do not horizontally overlap. For spots $3,4,5,6,7,8$, and 9 , $\mathrm{LSD}=66,219,323,100,247,153$, and 104 , respectively.

in the abundance of several key mitochondrial proteins (Sweetlove et al., 2002), it is possible that the higher accumulation of this enzyme in damaged tissue is required to replace non-functional mitochondrial proteins generated by the chilling stress. The 26SP is involved in the ATP-dependent degradation of ubiquitinated proteins, a system that plants use to control the abundance of key regulatory proteins and enzymes involved in diverse cellular processes such as hormone signaling and responses to pathogen and environmental stresses (Vierstra, 2009). Chilling stress might have triggered the accumulation of 26SP in damaged tissue as a cellular response aiming to degrade nonfunctional proteins and to avoid their possible cytotoxic effects. The removal of non-functional but potentially harmful polypeptides arising from misfolding, denaturation, or aggregation is important for the maintenance of cellular homeostasis. 
The photosynthetic enzyme ribulose-1,5-bisphosphate carboxylase/oxygenase (Rubisco) was more abundant in damaged tissue (spot 5, Fig. 3), which can be related to the fact that the main CI symptom observed in chilled fruit was the presence of immature (green) areas. Glycosidases such as $\alpha$-mannosidase have been demonstrated to increase their expression during ripening of tomato fruit (Jagadeesh et al., 2004), and the smaller accumulation of this enzyme in damaged pericarp (spot 8, Fig. 3 ) could be also related to uneven ripening as the main CI symptom. The urea cycle enzyme argininosuccinate lyase has been reported to be upregulated at low temperature, increasing the accumulation of metabolites with putative effects in cold tolerance such as citrulline, ornithine, putrescine, fumarate, and others (Cook et al., 2004). The accumulation of this enzyme was higher in non-damaged tissue (spot 9, Fig. 3) and it could be participating in the prevention of CI symptoms through the accumulation of these metabolites.

\section{Conclusions}

The main CI symptom of 'Imperial' tomato fruit was uneven ripening and color development, followed by pitting and decay. The proteome comparative analysis detected increased expression of a TPxI and a GR-RBP with chaperone activity in response to cold stress; these proteins showed a higher accumulation in pericarp without visible CI symptoms; moreover, tomato fruit stored at $5{ }^{\circ} \mathrm{C}$ for $5 \mathrm{~d}$ showed low injury levels, high expression of TPxI, and almost normal ripening. Thus, these enzymes may be playing an important role in cold response through redox sensing and regulation of gene expression at low temperature. The other CI-related proteins are involved in carbon metabolism, oxidative stress, photosynthesis, respiration, and protein processing and degradation. All of these proteins might be working together through different metabolic processes to maintain the cellular homeostasis under cold stress conditions. The characterization of these cold-stress-associated proteins contributes to a better understanding of the biochemical mechanisms associated with CI; these proteins represent potential markers to detect the disorder at an early stage or candidate genes for breeding cold-tolerant tomato genotypes.

\section{Literature Cited}

Bradford, M.M. 1976. A rapid and sensitive method for the quantitation of microgram quantities of protein utilizing the principle of protein-dye binding. Anal. Biochem. 72:248-254.

Cheng, T.S. and R.L. Shewfelt. 1988. Effect of chilling exposure of tomatoes during subsequent ripening. J. Food Sci. 53:1160-1162. Cho, M.R., K.H. Lee, Y.B. Hyun, I. Lee, and H.J. Kim. 2007. Proteome analysis of vernalization-treated Arabidopsis thaliana by matrixassisted laser desorption/ionization time-of-flight mass spectrometry. Bull. Korean Chem. Soc. 28:427-431.

Cook, D., S. Fowler, O. Fiehn, and M.F. Thomashow. 2004. A prominent role for the CBF cold response pathway in configuring the low-temperature metabolome of Arabidopsis. Proc. Natl. Acad. Sci. USA 101:15243-15248.

Ding, C.K., C.Y. Wang, K.C. Gross, and D.L. Smith. 2002. Jasmonate and salicylate induce the expression of pathogenesis-related protein genes and increase resistance to chilling injury in tomato fruit. Planta 214:895-901.

Emmermann, M., H.P. Braun, M. Arretz, and U.K. Schmitz. 1993. Characterization of the bifunctional cytochrome $\mathrm{c}$ reductase-processing peptidase complex from potato mitochondria. J. Biol. Chem. 268: 18936-18942.
Foyer, C.H. and G. Noctor. 2005. Redox homeostasis and antioxidant signaling: A metabolic interface between stress perception and physiological responses. Plant Cell 17:1866-1875.

Gomez, P., M.A. Ferrer, J.P. Fernandez-Trujillo, A. Calderon, F. Artes, M. Egea-Cortines, and J. Weiss. 2009. Structural changes, chemical composition and antioxidant activity of cherry tomato fruits (cv. Micro-Tom) stored under optimal and chilling conditions. J. Sci. Food Agr. 89:1543-1551.

Hodges, D.M., G.E. Lester, K.D. Munro, and P.M.A. Toivonen. 2004. Oxidative stress: Importance for postharvest quality. HortScience 39:924-929.

Jagadeesh, B.H., T.N. Prabha, and K. Srinivasan. 2004. Activities of glycosidases during fruit development and ripening of tomato (Lycopersicon esculentum L.): Implication in fruit ripening. Plant Sci. 166:1451-1459.

Kerdnaimongkol, K. and W.R. Woodson. 1999. Inhibition of catalase by antisense RNA increases susceptibility to oxidative stress and chilling injury in transgenic tomato plants. J. Amer. Soc. Hort. Sci. 124:330-336.

Kim, J.S., S.J. Park, K.J. Kwak, Y.O. Kim, J.Y. Kim, J. Song, B. Jang, C.H. Jung, and H. Kang. 2007a. Cold shock domain proteins and glycine-rich RNA-binding proteins from Arabidopsis thaliana can promote the cold adaptation process in Escherichia coli. Nucleic Acids Res. 35:506-516.

Kim, J.Y., S.J. Park, B. Jang, C.H. Jung, S.J. Ahn, C.H. Goh, K. Cho, O. Han, and H. Kang. 2007b. Functional characterization of a glycine-rich RNA-binding protein 2 in Arabidopsis thaliana under abiotic stress conditions. Plant J. 50:439-451.

Kim, Y.O., J.S. Kim, and H. Kang. 2005. Cold-inducible zinc fingercontaining glycine-rich RNA-binding protein contributes to the enhancement of freezing tolerance in Arabidopsis thaliana. Plant J. 42:890-900.

Lurie, S. and A. Sabehat. 1997. Prestorage temperature manipulations to reduce chilling injury in tomatoes. Postharvest Biol. Technol. 11:57-62.

Lyons, J.M. 1973. Chilling injury in plants. Annu. Rev. Plant Physiol. 24:445-466.

Madhavi, D.L. and D.H. Salunkhe. 1998. Tomato, p. 171-201. In: D.K. Salunkhe and S.S. Kadam (eds.). Handbook of vegetable science and technology: Production, composition, storage and processing. Marcel Dekker, New York.

Malacrida, C., E.M. Valle, and S.B. Boggio. 2006. Postharvest chilling induces oxidative stress response in the dwarf tomato cultivar MicroTom. Physiol. Plant. 127:10-18.

Marangoni, A.G., A.K. Smith, R.Y. Yada, and D.W. Stanley. 1989. Ultrastructural changes associated with chilling injury in maturegreen tomato fruit. J. Amer. Soc. Hort. Sci. 114:958-962.

Perkins, D.N., D.J. Pappin, D.M. Creasy, and J.S. Cottrell. 1999. Probability-based protein identification by searching sequence databases using mass spectrometry data. Electrophoresis 20:35513567.

Renaut, J., J.F. Hausman, and M.E. Wisniewski. 2006. Proteomics and low-temperature studies: Bridging the gap between gene expression and metabolism. Physiol. Plant. 126:97-109.

Rocco, M., C. D'Ambrosio, S. Arena, M. Faurobert, A. Scaloni, and M. Marra. 2006. Proteomic analysis of tomato fruits from two ecotypes during ripening. Proteomics 6:3781-3791.

Rodriguez-Vargas, S., F. Estruch, and F. Randez-Gil. 2002. Gene expression analysis of cold and freeze stress in baker's yeast. Appl. Environ. Microbiol. 68:3024-3030.

Saltveit, M.E. and L. Morris. 1990. Overview on chilling injury of horticultural crops, p. 3-15. In: C.Y. Wang (ed.). Chilling injury of horticultural crops. CRC Press, Boca Raton, FL.

Shevchenko, A., M. Wilm, O. Vorm, and M. Mann. 1996. Mass spectrometric sequencing of proteins silver-stained polyacrylamide gels. Anal. Chem. 68:850-858.

Shevchenko, A., S. Sunyaev, A. Loboda, P. Bork, W. Ens, and K.G. Standing. 2001. Charting the proteomes of organisms with unsequenced 
genomes by MALDI-quadrupole time-of-flight mass spectrometry and BLAST homology searching. Anal. Chem. 73:19171926.

Shikanai, T., T. Takeda, H. Yamauchi, S. Sano, K.I. Tomizawa, A. Yokota, and S. Shigeoka. 1998. Inhibition of ascorbate peroxidase under oxidative stress in tobacco having bacterial catalase in chloroplasts. FEBS Lett. 428:47-51.

Sweetlove, L.J., J.L. Heazlewood, V. Herald, R. Holtzapffel, D.A. Day, C.J. Leaver, and A.H. Millar. 2002. The impact of oxidative stress on Arabidopsis mitochondria. Plant J. 32:891-904.

Tripathi, B.N., I. Bhatt, and K.J. Dietz. 2009. Peroxiredoxins: A lessstudied component of hydrogen peroxide detoxification in photosynthetic organisms. Protoplasma 235:3-15.

Vierstra, R.D. 2009. The ubiquitin-26S proteasome system at the nexus of plant biology. Nat. Rev. Mol. Cell Biol. 10:385397.
Wang, W., R. Vignani, M. Scali, and M. Cresti. 2006. A universal and rapid protocol for protein extraction from recalcitrant plant tissues for proteomic analysis. Electrophoresis 27:2782-2786.

Wang, Y.J., M. Wisniewski, R. Meilan, M.G. Cui, R. Webb, and L. Fuchigami. 2005. Overexpression of cytosolic ascorbate peroxidase in tomato confers tolerance to chilling and salt stress. J. Amer. Soc. Hort. Sci. 130:167-173.

Weiss, J. and M. Egea-Cortines. 2009. Transcriptomic analysis of cold response in tomato fruits identifies dehydrin as a marker of cold stress. J. Appl. Genet. 50:311-319.

Yan, S.P., Q.Y. Zhang, Z.C. Tang, W.A. Su, and W.N. Sunday. 2006. Comparative proteomic analysis provides new insights into chilling stress responses in rice. Mol. Cell. Proteomics 5:484-496.

Yang, J., M. Fu, Y. Zhao, and L. Mao. 2009. Reduction of chilling injury and ultrastructural damage in cherry tomato fruits after hot water treatment. Agr. Sci. China 8:304-310. 